\title{
Perilaku Kerja Inovatif dan Efikasi Diri Kreatif pada Mahasiswa
}

\author{
Salsabiah Firdausiah, Arum Etikariena \\ Program Studi Psikologi, Fakultas Psikologi, Universitas Indonesia, Depok
}

Abstrak: Sekarang ini perusahaan membutuhkan karyawan dengan perilaku kerja inovatif. Oleh karena itu, sangat penting untuk mempersiapkan mahasiswa sebagai calon tenaga kerja agar memilikinya. Akan tetapi, penelitian tentang perilaku kerja inovatif pada mahasiswa serta variabel yang berhubungan dengannya masih jarang dilakukan, khususnya di Indonesia. Penelitian korelasional ini kemudian dilakukan dengan tujuan untuk melihat hubungan antara efikasi diri kreatif dan perilaku kerja inovatif pada mahasiswa. Responden berjumlah 539 mahasiswa jenjang S1 di Universitas Indonesia dan merupakan mahasiswa yang minimal sedang menempuh semester empat. Penelitian ini adalah penelitian kuantitatif dengan menggunakan teknik statistik Pearson Correlation. Peneliti menemukan bahwa terdapat hubungan yang positif dan signifikan antara efikasi diri kreatif dan perilaku kerja inovatif pada mahasiswa, $r(538)=$ $.67, \mathrm{p}=.00(\mathrm{p}<.01$, one-tailed). Effect size untuk analisis ini termasuk large effect karena $r>.50$. Hasil penelitian ini bisa memberikan manfaat berupa menambah literatur tentang perilaku kerja inovatif pada mahasiswa.

Kata Kunci: efikasi diri kreatif, mahasiswa, perilaku kerja inovatif

\section{Innovative Work Behavior and Creative Self Efficacy on College Student}

Abstract. Recently companies need employees with innovative work behavior. Therefore, it is very important to prepare students as employee candidates to own this behavior since they are still in college. However, research on innovative work behavior among college students and the variables associated with it is still quite few, especially in Indonesia. This correlational research was then conducted to look at the relationship between creative self-efficacy and innovative work behavior among college students. The respondents were 539 undergraduate students at Universitas Indonesia, at least in fourth semester. This research is a quantitative study, using the Pearson Correlation statistical technique. It argues that there is a positive and significant relationship between creative self-efficacy and innovative work behavior among college students, $r(538)=.67, p=.00(p<.01$, one-tailed). The effect size is quite large, because it has $r$ $>.50$. This result might contribute in adding literature on innovative work behavior among college students.

Keywords: college student, creative self-efficacy, innovative work behavior

Korespondensi: Salsabiah Firdausiah. Email: salsabiah.firdausiah@ui.ac.id 
Inovasi memiliki peran yang sangat penting untuk menentukan keberhasilan bisnis, kinerja, dan kelangsungan jangka panjang serta menjadi sumber kehidupan dari organisasi atau perusahaan (Agarwal, 2014; Janssen, 2000; Martín et al., 2017; Omri, 2015; Slåtten, 2014). Menurut Antoncic dan Hisrich (2001), salah satu cara untuk mengembangkan bisnis di perusahaan yang kecil maupun besar adalah dengan memperbolehkan karyawan untuk mengutarakan dan mengimplementasikan inovasinya. Pada saat berinovasi, karyawan akan mengambil inisiatif untuk memperkenalkan proses baru, produk baru, pasar baru, atau kombinasi dari ketiganya kepada perusahaan. Perusahaan akan mampu berkembang dan bertahan dalam persaingan di pasarnya jika karyawannya bisa mengimplementasikan ide-ide baru yang mereka buat ke dalam pekerjaan (Åmo \& Kolvereid, 2005).

Pentingnya inovasi bagi kelangsungan serta untuk mencapai tujuan keseluruhan dari perusahaan membuatnya perlu untuk mempersiapkan serta mendukung aktivitas inovasi bagi seluruh karyawannya (Agarwal, 2014; Slåtten, 2014). Akan tetapi, perlu menjadi pertimbangan juga bahwa sangat penting untuk mempersiapkan calon tenaga kerja sejak berada di sekolah seperti di jenjang SMA/K atau perguruan tinggi agar nantinya dapat menampilkan perilaku kerja inovatif di pekerjaan (Etikariena, 2017). Memperkenalkan lebih awal mengenai perilaku kerja inovatif kepada siswa di jenjang pendidikan tinggi sebelum bekerja menjadi penting karena merupakan sumber utama inovasi-inovasi di masa depan bagi perusahaan (Martín et al, 2017; Roffeei et al., 2017). Jika mahasiswa sebagai calon tenaga kerja sudah memiliki perilaku kerja inovatif, maka perusahaan bisa menghemat waktu serta biaya karena kemungkinan tidak perlu lagi melatih perilaku kerja inovatif dari karyawan perusahaan tersebut.

Penelitian mengenai perilaku kerja inovatif lebih banyak dilakukan di lingkungan kerja di bandingkan dengan di area pendidikan khususnya pendidikan tinggi (Roffeei et al., 2017). Penelitian mengenai perilaku kerja inovatif pada mahasiswa ini kemudian dilakukan juga karena terdapat perbedaan perilaku kerja inovatif antara karyawan dan mahasiswa. Karyawan menampilkan perilaku kerja inovatif di lingkungan tempat bekerja dengan tujuan untuk menguntungkan perusahaan. Perilaku kerja inovatif dari karyawan ini di antaranya berupa mengembangkan produk-produk baru, pasar baru, atau meningkatkan rutinitas bisnis di tempat kerja (Baumann, 2011). Karyawan cenderung menampilkan perilaku kerja inovatif jika merasa usaha tersebut diberikan reward/upah yang seimbang atau adil (Janssen, 2000), dan juga akan sangat berhati-hati untuk menampilkan perilaku kerja inovatif karena menganggap perilaku ini adalah perilaku yang beresiko untuk 
posisi karyawan di organisasi atau perusahaan (Bysted \& Jespersen, 2014).

Di sisi lain, mahasiswa menampilkan perilaku kerja inovatif untuk menguntungkan individu pada hal yang berhubungan dengan tugas-tugas akademis. Mahasiswa cenderung melakukan hal tersebut untuk menyelesaikan atau mengerjakan tuntutan tugas akademis dengan lebih baik (Martín et al, 2017) dan tidak dimotivasi oleh upah seperti pada karyawan. Pada mahasiswa, konsekuensi negatif dari menampilkan perilaku kerja inovatif ini juga jarang ditemui sehingga kemungkinan mahasiswa memiliki lebih banyak kesempatan dan lebih berani untuk menampilkan perilaku ini (Hammond et al., 2011) Dikarenakan adanya perbedaan-perbedaan ini, peneliti akan meneliti mengenai perilaku kerja inovatif yang akan disesuaikan dengan konteks mahasiswa yang mana perilaku kerjanya adalah yang berhubungan dengan penyelesaian tugas-tugas sebagai mahasiswa untuk menambah penelitian di area pendidikan tinggi.

Dasar dari inovasi merupakan ide dan yang mengembangkan, membawa, bereaksi dan dapat memodifikasi ide-ide tersebut adalah individu itu sendiri. Proses dari mengimplementasikan ide yang merupakan hal terpenting dalam perilaku inovatif berlangsung dalam pola yang kompleks yang kadang tidak berhubungan dengan lingkungan seseorang, melainkan proses yang ada dalam dirinya sendiri atau internal (Scott \& Bruce, 1994). Maka dari itu, peneliti akan meneliti tentang faktor internal yang berhubungan dengan perilaku kerja inovatif individu, khususnya mahasiswa. Faktor internal dari individu yang akan diteliti kaitannya dengan perilaku inovatif adalah efikasi diri kreatif. Efikasi diri kreatif merupakan keyakinan individu pada kemampuannya untuk mengerahkan motivasi, sumber daya kognitif, serta tindakan-tindakan yang dibutuhkan demi memenuhi tuntutan pada situasi tertentu dan untuk memproduksi sesuatu yang kreatif atau untuk melakukan tugas-tugas tertentu dalam proses inovasi (Hsu et al., 2011; Slåtten, 2014; Tierney \& Farmer, 2002).

Egan (2005) serta Tierney dan Farmer (2011) menyatakan bahwa mengetahui bagaimana cara untuk mengembangkan efikasi diri kreatif karyawan merupakan langkah yang sangat penting bagi perusahaan untuk dapat meningkatkan perilaku kerja inovatif dari karyawan. Inovasi adalah perilaku yang beresiko (Yuan \& Woodman, 2010), efikasi diri kreatif dibutuhkan agar individu bisa mengatasi ketidakpastian dan kegagalan dalam proses inovasi ini (Hsu et al., 2011). Jadi, dapat disimpulkan bahwa efikasi diri kreatif ini merupakan faktor internal yang penting untuk diteliti hubungannya dengan perilaku kerja inovatif dan penting untuk dimiliki oleh individu termasuk mahasiswa sebagai calon tenaga kerja yang merupakan sampel dalam penelitian ini.

Perilaku kerja inovatif diartikan sebagai intensi individu untuk menciptakan, memperkenalkan, dan menerapkan ide-ide baru pada pekerjaan, kelompok, atau organisasinya 
(Scott \& Bruce, 1994). Janssen (2000) kemudian melengkapi definisi dari Scott dan Bruce (Scott \& Bruce, 1994) dengan mendefinisikan perilaku kerja inovatif sebagai penciptaan, pengenalan, dan pengaplikasian ide-ide baru secara disengaja untuk memberikan keuntungan pada pekerjaan, kelompok, atau organisasi. (Janssen, 2000) sendiri membatasi perilaku kerja inovatif ini sebagai usaha yang disengaja untuk menyediakan hasil baru yang bermanfaat. Definisi dari perilaku kerja inovatif yang milik Scott dan Bruce (1994) kemudian digunakan dalam penelitian ini karena dikatakan bahwa kreatifitas adalah bagian penting dari perilaku kerja inovatif, terutama di awal, untuk menghasilkan ide-ide baru dan berguna meskipun perilaku kerja inovatif merupakan proses yang lebih dari kreatifitas (Scott \& Bruce, 1994).

Berdasarkan Scott dan Bruce (1994) perilaku kerja inovatif adalah perilaku kompleks yang terdiri dari tiga tahapan, yang pertama adalah tahap menciptakan ide (idea generation), tahap ini dimulai dari individu menyadari adanya masalah atau munculnya peluang dan kemudian membuat ide atau solusi yang baru atau menga dopsi ide yang sudah ada untuk mengatasinya. Individu membuat konsep-konsep untuk tujuan peningkatan atau perbaikan yang berkaitan dengan produk baru, jasa, proses kerja, atau ketika ingin memasuki pasar baru (Kleysen \& Street, 2001). Yang kedua adalah tahap mempromosikan ide (idea promotion), pada tahap ini individu mencari hal yang bisa mendukung idenya, bisa berasal dari dalam organisasi maupun dari luar. Yang terakhir adalah tahap merealisasikan ide-ide baru dan berguna (idea realization) (Janssen, 2000; Scott \& Bruce, 1994). Pada tahap ini individu berusaha untuk merealisasikan ide dengan menciptakan prototipe dari ide atau melakukan cara lain dalam rangka untuk mengimplementasikan.

Ketika diimplementasikan, inovasi ini akan menjadi bagian dari proses kerja sehari-hari di perusahaan atau organisasi (Kleysen \& Street, 2001).

Terdapat beberapa anteseden dari perilaku kerja inovatif, di antaranya adalah jenis kelamin yang dbutirukan merupakan faktor yang dapat membedakan perilaku kerja inovatif antarindividu (Janssen, 2000; Østergaard et al, 2011). Penelitian dari Janssen (2000) menunjukkan bahwa laki-laki memiliki perilaku kerja inovatif yang lebih tinggi dibandingkan perempuan. Hal ini dapat terjadi karena adanya perbedaaan peran pekerjaan dan tingkat jabatan di organisasi atau perusahaan. Laki-laki cenderung lebih diuntungkan oleh stereotipe yang ada bahwa laki-laki lebih cocok untuk posisi jabatan yang tinggi dibandingkan perempuan. Hal tersebut menyebabkan perempuan cenderung tidak memiliki kesempatan untuk menerapkan perilaku kerja inovatif dalam pekerjaan karena tidak adanya akses atau tidak berada pada posisi yang bisa dengan mudah menerapkan perilaku kerja 
inovatif ini (W. Kim et al., 2016; Park et al., 2017; Powell et al., 2002).

Selanjutnya ada efikasi diri, yang mampu memengaruhi motivasi individu untuk melakukan inovasi. Pada saat akan meneliti hubungan efikasi diri dengan perilaku kerja inovatif maka harus dibedakan antara efikasi diri kerja yaitu kepercayaan seseorang terhadap kompetensinya dalam melakukan tugas dan efikasi diri kreatif yaitu kepercayaan seseorang terhadap kompetensinya terkait performa kreatif. Keduanya berhubungan dengan hasil kreatif dan inovatif dari seseorang (Hammond et al., 2011; Tierney \& Farmer, 2002). Kemudian, penelitian yang dilakukan oleh Martin et al. (2017) menunjukkan bahwa terdapat perbedaan pada perilaku kerja inovatif antar mahasiswa berdasarkan fakultasnya. Mahasiswa dari Fakultas Seni Rupa menunjukkan perilaku kerja inovatif yang lebih tinggi dibandingkan mahasiswa lain. Hal tersebut terjadi karena mahasiswa Seni Rupa memiliki kebebasan yang lebih untuk menerapkan ide-ide inovatif nya dan memiliki kesempatan yang lebih banyak untuk menerapkan cara-cara baru dalam menyelesaikan tugas-tugas akademisnya.

Dari faktor-faktor telah dijelaskan di atas, penelitian ini akan fokus pada faktor internal yaitu efikasi diri kreatif. Efikasi diri kreatif dipilih karena merupakan faktor penting dalam tahap menciptakan ide (West, 2002), faktor yang mampu memberikan motivasi kepada individu untuk melakukan inovasi (Hammond et al., 2011), dan faktor yang mampu membantu individu agar dapat menghadapi hambatanhambatan yang muncul ketika melakukan inovasi (Yuan \& Woodman, 2010).

Menurut Bandura (1997), efikasi diri kreatif adalah bentuk spesifik dari efikasi diri milik Bandura yang berarti keyakinan individu pada kemampuannya untuk mengerahkan motivasi, sumber daya kognitif dan tindakantindakan yang dibutuhkan agar bisa memenuhi tuntutan pada situasi tertentu dan untuk memproduksi sesuatu atau keluaran yang kreatif atau untuk melakukan tugas-tugas tertentu dalam proses inovasi (Hsu et al., 2011; Slåtten, 2014; Tierney \& Farmer, 2002). Penelitian ini menggunakan definisi efikasi diri kreatif dari Tierney dan Farmer (2002) yaitu keyakinan seseorang terhadap kemampuannya untuk memproduksi hasil yang kreatif, baru, dan berguna. Definisi tersebut dipilih karena mereka adalah yang pertama kali meneliti dan mengembangkan alat ukur mengenai efikasi diri kreatif berdasarkan teori efikasi diri milik Bandura. Definisi milik Tierney dan Farmer (2002) juga banyak digunakan pada penelitian mengenai performa inovatif dari individu (Chang \& Yang, 2012; Hsu et al, 2011; Ng \& Lucianetti, 2016; Slåtten, 2014).

MenurutZhou dan George (2001) perilaku kerja inovatif ini melibatkan pembentukan dan pengimplementasian ide-ide kreatif di lingkungan kerja. Pada saat individu ingin melakukan sebuah inovasi individu harus menerapkan ide kreatif, disaat individu tersebut itu memiliki efikasi diri 
kreatif maka perilaku kerja inovatif akan tinggi daripada yang tidak memiliki atau rendah efikasi diri kreatifnya (Abdullah et al,, 2016). Individu yang memiliki efikasi diri kreatif yang tinggi menghabiskan lebih banyak waktu untuk proses kognitif yang berhubungan dengan kreativitas dalam tahap mengenali masalah dan peluang serta dalam tahap menghasilkan ide atau solusi. Upaya individu tersebut dalam mencari dukungan untuk ide dan untuk menghasilkan prototipenya juga akan lebih besar. Hal tersebut membuatnya dapat mengerjakan pekerjaan yang spesifik dengan lebih baik dan bisa meraih tujuan inovasi (Hsu et al., 2011; Tierney \& Farmer, 2002). Selain itu, Supriatna (2019) menyatakan bahwa individu yang efikasi diri kreatifnya tinggi akan cenderung tidak mudah menyerah serta akan tetap bersikap positif saat dihadapkan dengan halangan atau komentar negatif dari orang lain ketika melakukan inovasi. Mereka juga akan terus berpikir secara kritis untuk menemukan ide atau solusi yang inovatif.

Berdasarkan pemaparan di atas, peneliti memiliki hipotesis bahwa terdapat hubungan yang positif dan signifikan antara efikasi diri kreatif dan perilaku kerja inovatif pada mahasiswa. Beberapa penelitian yang telah disebutkan sebelumnya memang telah menemukan adanya hubungan yang positif dan signifikan antara efikasi diri kreatif dan perilaku kerja inovatif. Akan tetapi, banyak di antaranya merupakan penelitian yang respondennya adalah karyawan di sebuah perusahaan atau organisasi. Meskipun ada yang menelitinya pada mahasiswa, penelitian tersebut dilakukan pada mahasiswa di luar negeri dan dirasa juga masih jarang ditemukan. Mahasiswa di Indonesia kemungkinan memiliki perbedaan dengan mahasiswa di luar negeri terkait dengan perilaku kerja inovatifnya. Meskipun disebutkan sebelumnya bahwa mahasiswa memiliki kesempatan yang lebih banyak dan kemungkinan lebih berani untuk menampilkan perilaku kerja inovatif dibandingan karyawan, akan tetapi perilaku kerja inovatif mahasiswa di Indonesia cenderung kurang mendapat penghargaan dari lingkungan sekitarnya sehingga kemungkinan berhubungan dengan perilaku kerja inovatif yang akan mahasiswa tampilkan. Oleh karena itu, diperlukan penelitian untuk mengetahui lebih banyak informasi mengenai perilaku kerja inovatif pada mahasiswa di Indonesia. Jika digambarkan maka bagan dari penelitian ini adalah sebagai berikut:

\section{Gambar 1}

Bagan Penelitian Hubungan antara Efikasi Diri Kreatif dan Perilaku Kerja Inovatif pada Mahasiswa

\begin{tabular}{|c|c|}
\hline $\begin{array}{c}\text { Anteseden: } \\
\text { Efikasi Diri } \\
\text { Kreatif }\end{array}$ & $\begin{array}{c}\text { Outcome: } \\
\text { Perilaku } \\
\text { Kerja Inovatif }\end{array}$ \\
\hline
\end{tabular}




\section{Metode}

Penelitian ini termasuk dalam penelitian dengan tipe korelasional, exploratory, dan penelitian kuantitatif. Terkait dengan desain, penelitian ini termasuk penelitian dengan desain non-experimental karena tidak ada manipulasi terhadap variabel-variabelnya dan juga desain cross-sectional, yang pengambilan datanya hanya satu kali (Gravetter \& Forzano, 2012; Kumar, 2011).

\section{Responden penelitian}

Responden yang dipilih adalah mahasiswa S1 di Universitas "X" dan yang sedang menjalani semester empat atau lebih karena dianggap sudah beradaptasi dengan baik dengan lingkungan universitas dan dalam kehidupan menjadi seorang mahasiswa. Diasumsikan koresponden sudah mampu dan berani untuk melakukan inovasi dalam mengerjakan tugas-tugas sebagai mahasiswa. Mahasiswa S1 tahun pertama tidak diikutsertakan karena masih dalam masa transisi dari SMA ke universitas (Southall et al,, 2016; Trautwein \& Bosse, 2017).

Peneliti akan mencari responden dengan jumlah kurang lebih 30 orang di setiap fakultas karena Gravetter dan Wallnau (2013) menyatakan bahwa diperlukan minimal 30 sampel agar distribusi datanya mendekati kurva normal. Ada sebanyak 14 fakultas untuk jenjang sarjana S1 di Universitas Indonesia, jadi penelitian ini diharapkan mendapatkan responden sebanyak 420 orang yang datanya dapat diolah. Teknik pemilihan responden adalah dengan non-probability sampling method dengan jenis convenience sampling.

\section{Instrumen penelitian}

Pengambilan data dilakukan dengan menyebarkan kuesioner yang akan diisi oleh responden secara daring. Teknik pengambilan data dengan kuesioner daring ini dipilih agar lebih efektif untuk mendapatkan responden dengan jumlah yang banyak serta lebih efisien dalam pengisian jawabannya. Alat ukur yang digunakan adalah alat ukur Perilaku Kerja Inovatif dari Janssen (2000) yang dikembangkan berdasarkan definisi perilaku kerja inovatif dari Scott dan Bruce (1994). Alat ukur ini merupakan alat ukur yang unidimensional karena berdasarkan definisi dari Scott dan Bruce (1994) perilaku kerja inovatif merupakan konstruk yang unidimensional, perilaku kerja inovatif dinyatakan memiliki tiga tahapan yang saling berkesinambungan bukan dimensi yang berbeda-beda. Semua butir dalam tes akan direspon pada skala Likert mulai dari 1 jika individu belum pernah melakukan sampai dengan 6 jika individu selalu melakukan. Ada tiga butir di masing-masing tahapan dari perilaku kerja inovatif pada alat ukur ini, sehingga totalnya ada sembilan butir.

Pada penelitian yang telah dilakukan oleh Etikariena dan Muluk (2014), alat ukur ini memiliki Alpha Cronbach sebesar .80. Menurut Kaplan dan Saccuzzo (2009) alat ukur ini 
reliabel karena sebuah tes paling tidak memiliki nilai koefisien sebesar .70-.80 untuk dapat disebut reliabel. Peneliti menggunakan alat ukur yang sudah diterjemahkan oleh Etikariena dan Muluk (2014) ke dalam Bahasa Indonesia yang kemudian butir disesuaikan untuk responden mahasiswa. Contoh dari butir yang sudah dimodifikasi seperti di Tabel 1.

\section{Tabel 1}

Distribusi Butir Alat Ukur Perilaku Kerja Inovatif

\begin{tabular}{lll}
\hline \multicolumn{1}{c}{ Tahap } & $\begin{array}{l}\text { Contoh Butir pada Alat } \\
\text { Ukur untuk Karyawan }\end{array}$ & $\begin{array}{l}\text { Contoh Butir Modifikasi } \\
\text { untuk Mahasiswa }\end{array}$ \\
\hline $\begin{array}{l}\text { Tahap menciptakan } \\
\text { ide }\end{array}$ & $\begin{array}{l}\text { Mencari metode kerja yang } \\
\text { baru di pekerjaan saya. }\end{array}$ & $\begin{array}{l}\text { Mencari cara baru untuk } \\
\text { mengerjakan tugas saya. }\end{array}$ \\
$\begin{array}{l}\text { Tahap } \\
\text { mempromosikan ide }\end{array}$ & $\begin{array}{l}\text { Mendapatkan persetujuan } \\
\text { untuk ide-ide inovatif yang } \\
\text { saya sampaikan. }\end{array}$ & $\begin{array}{l}\text { Mendapatkan dukungan } \\
\text { untuk ide-ide inovatif yang } \\
\text { saya sampaikan. }\end{array}$ \\
$\begin{array}{l}\text { Tahap merealisasikan ide-ide } \\
\text { ide }\end{array}$ & $\begin{array}{l}\text { Mewujudkan inovatif menjadi aplikasi } \\
\text { atau program yang dapat } \\
\text { dilaksanakan. }\end{array}$ & $\begin{array}{l}\text { Mewujudkan } \\
\text { inovatif menjadi sesuatu } \\
\text { yang bisa dimanfaatkan } \\
\text { oleh orang lain. }\end{array}$ \\
\hline
\end{tabular}

Sedangkan, untuk mengukur efikasi diri kreatif pada mahasiswa alat ukur yang akan digunakan adalah yang diciptakan oleh Tierney dan Farmer (2002). Alat ukur ini juga merupakan alat ukur yang unidimensional karena berdasarkan definisi dari Tierney dan Farmer (2002) efikasi diri kreatif adalah konstruk yang unidimensional Ada empat butir dalam alat ukur ini (misal,"Saya memiliki keyakinan pada kemampuan saya untuk memecahkan masalah secara kreatif") (Hsu et al., 2011). Semua butir dalam pengukuran akan direspon pada skala Likert mulai dari 1 jika individu sangat tidak setuju dengan pernyataam sampai 6 jika individu sangat setuju dengan pernyataan. Alat ukur ini memiliki Alpha Cronbach sebesar .80 dalam penelitian Hsu et al. (2011), jadi merupakan alat ukur yang reliabel.

\section{Prosedur penelitian}

Peneliti terlebih dahulu menerjemahkan butir dalam alat ukur Efikasi diri Kreatif yang digunakan ke dalam Bahasa Indonesia sebelum menyebarkannya dan kemudian memeriksa apakah terjemahan tersebut sudah benar dengan meminta pihak lain untuk melakukan penerjemahan kembali ke dalam Bahasa Inggris. Hal tersebut dilakukan untuk melihat apakah hasil terjemahannya sudah sesuai. Butir-butir alat ukur Perilaku Kerja Inovatif tidak perlu diterjemahkan karena menggunakan alat ukur yang telah diterjemahkan dalam penelitian Etikariena dan Muluk (2014). Peneliti kemudian menyesuaikan butir-butirnya untuk responden mahasiswa agar lebih relevan dengan keadaan mereka dan kemudian melakukan uji 
keterbacaan dari alat ukur yang digunakan pada tanggal 13 Maret 2020. Peneliti meminta bantuan kepada 10 mahasiswa Universitas "X" dari semua rumpun (rumpun sosial humaniora, rumpun saintek, dan rumpun ilmu kesehatan) untuk mengerjakan alat ukur tersebut. Setelah selesai mengerjakan, peneliti menanyakan kepada responden mengenai kesan ataupun saran terhadap keseluruhan butir dalam alat ukur.

Hasilnya, ada beberapa butir dalam alat ukur perilaku kerja inovatif yang dimodifikasi kembali berdasarkan saran-saran yang diberikan oleh responden. Contohnya adalah butir pada tahap mempromosikan ide, sebelumnya berbunyi “Mendapatkan dukungan untuk ide-ide inovatif yang saya sampaikan" kemudian dimodifikasi menjadi "Berupaya mendapatkan dukungan untuk ide-ide inovatif yang saya sampaikan". Sedangkan, butir-butir dalam alat ukur efikasi diri kreatif dianggap sudah cukup jelas bagi responden sehingga tidak memerlukan modifikasi.

Peneliti kemudian akan menyebarkan alat ukur penelitian dalam bentuk kuesioner, saat menyusun kuesioner peneliti menambahkan satu butir berupa Instructed Response Item (IRI). Penambahan butir ini bertujuan untuk memeriksa apakah peserta membaca semua butir dengan sungguhsungguh atau tidak. Butir tersebut yaitu, "Pada pernyataan ini mohon pilih jawaban nomor enam (sangat setuju)". Data dari responden yang gagal dalam memberikan jawaban yang benar pada Instructed Response Item kemudian akan dihapus karena akan menurunkan kualitas dari data dalam penelitian (Berinsky et al., 2013; Oppenheimer et al., 2009).

Selanjutnya, pilot study dilakukan pada tanggal 14 sampai 16 Maret 2020 dengan menyebarkan kuesioner secara daring melalui media sosial. Responden pada pilot study ini terdiri dari mahasiswa Universitas "X" dan mahasiswa universitas lain di daerah Jabodetabek. Setelah selesai, peneliti kemudian menguji reliabilitas dari alat ukur Perilaku Kerja Inovatif dan Efikasi Diri Kreatif. Berdasarkan hasil uji reliabilitas, kedua alat ukur yang digunakan ini terbukti reliabel. Alat ukur Perilaku Kerja Inovatif memiliki Alpha Cronbach sebesar .88 dan alat ukur Efikasi Diri Kreatif sendiri memiliki Alpha Cronbach sebesar .83. Semua butir dalam kedua alat ukur tersebut juga memiliki skor corrected item-total correlation yang lebih dari .30 yang menandakan bahwa semua butir dalam masingmasing alat ukur telah berkorelasi dengan keseluruhan skor dalam alat ukur (Field, 2009). Berdasarkan hasil-hasil tersebut, peneliti tidak melakukan revisi pada alat ukur Perilaku Kerja Inovatif dan Efikasi diri Kreatifini karena semua alat ukur telah teruji reliabel.

Peneliti selanjutnya melakukan analisis proportion of endorsement untuk melihat kecenderungan peserta untuk menjawab setuju atau tidak setuju. Hasilnya, hanya ada satu butir dalam alat ukur Perilaku Kerja Inovatif yang menunjukkan indeks endorsement yang lebih 
dari .85, hasil tersebut menurut Milon dan Bloom berarti ada social desirability yang memengaruhi responden menjawab setuju pada butir tersebut. Butir tersebut adalah "Mencari cara baru untuk mengerjakan tugas saya" yang indeks endorsement adalah .96. Sedangkan, pada alat ukur Efikasi Diri Kreatif tidak ditemukan butir yang indeks endorsement-nya lebih dari .85, hasil ini menandakan bahwa tidak ada pengaruh social desirability dalam responden menjawab butir-butir alat ukur ini.

Selanjutnya, peneliti menggabungkan kuesioner di Google Form untuk kemudian dapat disebarkan secara daring kepada mahasiswa Universitas " $\mathrm{X}$ " melalui media sosial. Setelah pengambilan data selesai dilakukan peneliti kemudian akan menganalisis untuk mengetahui hasil akhir dari penelitian agar mampu mendapatkan jawaban dari permasalahan penelitian. Peneliti akan melakukan analisis pendahuluan untuk memeriksa reliabilitas kuesioner penelitian. Setelah itu, dengan bantuan perangkat lunak IBM SPSS versi 24 peneliti menganalisis data dengan menggunakan berbagai teknik analisis statistika sebagai berikut: statistik deskriptif, Pearson Correlation, dan Analysis of Variance (ANOVA).

\section{Hasil}

Penelitian ini bertujuan untuk mengetahui lebih banyak informasi mengenai perilaku kerja inovatif pada mahasiswa di Indonesia. Setelah menyebarkan kuesioner selama 28 hari dari tanggal 21 Maret sampai dengan 17 April 2020 peneliti mendapatkan 650 responden, namun ada 111 responden yang datanya tidak dapat dianalisis karena tidak lolos pemeriksaan atensi atau salah dalam menjawab instructed response item dan menyisakan 539 responden yang datanya bisa digunakan untuk dianalisis lebih lanjut. Berdasarkan Tabel 2, dapat diketahui bahwa mayoritas responden berusia 21 tahun (29.3\%) dan mayoritas adalah perempuan (65.7\%). Mayoritas responden sedang menjalani semester empat di Universitas "X" (35.8\%), tinggal bersama dengan orang tua mereka (67.3\%), dan mengikuti kepanitiaan $(28 \%)$.

Berikut merupakan tabel karakteristik umum responden berdasarkan data demografis usia, jenis kelamin, semester yang sedang dijalani, lokasi tempat tinggal saat ini, dan kegiatan non akademis di dalam atau di luar kampus: 


\section{Tabel 2}

Karakteristik Umum Responden

\begin{tabular}{|c|c|c|}
\hline Karakteristik & $n$ & $\%$ \\
\hline \multicolumn{3}{|l|}{ Usia } \\
\hline 18 tahun & 14 & 2.6 \\
\hline 19 tahun & 109 & 20.2 \\
\hline 20 tahun & 158 & 29.3 \\
\hline 21 tahun & 174 & 32.3 \\
\hline 22 tahun & 65 & 12.1 \\
\hline 23 tahun & 18 & 3.3 \\
\hline 25 tahun & 1 & 0.2 \\
\hline \multicolumn{3}{|l|}{ Jenis kelamin } \\
\hline Perempuan & 354 & 65.7 \\
\hline Laki-laki & 185 & 34.3 \\
\hline \multicolumn{3}{|l|}{ Semester yang Sedang Dijalani } \\
\hline Semester 4 & 193 & 35.8 \\
\hline Semester 6 & 154 & 28.6 \\
\hline Semester 8 & 189 & 35.1 \\
\hline Semester 10 & 3 & 0.6 \\
\hline \multicolumn{3}{|l|}{ Lokasi tempat tinggal saat ini } \\
\hline Sendiri (kost/apartment/kontrak) & 156 & 28.9 \\
\hline Bersama orang tua & 363 & 67.3 \\
\hline Bersama kerabat keluarga lain & 14 & 2.6 \\
\hline Bersama kakak kandung & 2 & 0.4 \\
\hline Asrama & 3 & 0.6 \\
\hline Bersama teman & 1 & 0.2 \\
\hline \multicolumn{3}{|l|}{ Kegiatan Non Akademis di Dalam atau Di Luar Kampus } \\
\hline Organisasi (BEM, MPM, DPM, dll) & 255 & 26.7 \\
\hline Kepanitiaan & 267 & 28 \\
\hline UKM Kesenian, Olahraga, Kerohanian, atau sejenisnya & 139 & 14.5 \\
\hline Paguyuban/Komunitas & 97 & 10.2 \\
\hline Berwirausaha & 44 & 4.6 \\
\hline Tidak mengikuti kegiatan apapun & 103 & 10.8 \\
\hline Bekerja/Magang/Part time/Freelance & 28 & 2.9 \\
\hline Mengajar/Asisten/Staf Bimbel & 9 & 0.9 \\
\hline Kegiatan Keagamaan & 6 & 0.6 \\
\hline Volunteer/Kegiatan Sosial & 3 & 0.3 \\
\hline Les & 2 & 0.2 \\
\hline Lainnya (Gym, Riset, Band, Proyek) & 3 & 0.3 \\
\hline$N$ & 539 & 100 \\
\hline
\end{tabular}


Selain itu, peneliti juga melihat karakteristik umum responden berdasarkan data demografis fakultas yang dikelompokkan sesuai dengan rumpun ilmunya. Berikut ini merupakan tabel yang menggambarkan karakteristik umum responden berdasarkan data demografis fakultas responden:

\section{Tabel 3}

Karakteristik Umum Responden Berdasarkan Fakultas

\begin{tabular}{|c|c|c|}
\hline Karakteristik & $n$ & $\%$ \\
\hline \multicolumn{3}{|l|}{ Rumpun Ilmu Kesehatan } \\
\hline Kedokteran & 13 & 2.4 \\
\hline Kedokteran Gigi & 25 & 4.6 \\
\hline Kesehatan Masyarakat & 27 & 5 \\
\hline Ilmu Keperawatan & 25 & 4.6 \\
\hline Farmasi & 32 & 5.9 \\
\hline \multicolumn{3}{|l|}{ Rumpun Ilmu Sains dan Teknologi } \\
\hline Matematika dan Ilmu Pengetahuan Alam & 76 & 14.1 \\
\hline Teknik & 87 & 16.1 \\
\hline Ilmu Komputer & 26 & 4.8 \\
\hline \multicolumn{3}{|l|}{ Rumpun Ilmu Sosial dan Humaniora } \\
\hline Hukum & 19 & 3.5 \\
\hline Ekonomi \& Bisnis & 37 & 6.9 \\
\hline Ilmu Pengetahuan Budaya & 59 & 10.9 \\
\hline Psikologi & 53 & 9.8 \\
\hline Ilmu Sosial dan Ilmu Politik & 44 & 8.2 \\
\hline Ilmu Administrasi & 16 & 3 \\
\hline$N$ & 539 & 100 \\
\hline
\end{tabular}

Berdasarkan Tabel 3, dapat dikelompokkan berdasarkan rumpun disimpulkan bahwa mayoritas responden ilmunya mayoritas responden merupakan merupakan mahasiswa/mahasiswi dari mahasiswa Rumpun Ilmu Sosial dan Fakultas Teknik (16.1\%). Jika Humaniora(42.3\%).

\section{Tabel 4}

Hasil Korelasi antara Perilaku Kerja Inovatif dan Efikasi Diri Kreatif

\begin{tabular}{lcc}
\hline \multicolumn{1}{c}{ Variabel } & 1 & 2 \\
\hline 1. Perilaku Kerja Inovatif & - & $.67^{* *}$ \\
2. Efikasi Diri Kreatif & $.67^{* *}$ & - \\
& .00 \\
\hline
\end{tabular}

Catatan. $^{* *} \mathrm{p}<.01$ (one-tailed), $N=539$. 
Peneliti kemudian melakukan pengujian statistik untuk mendapatkan hasil utama penelitian. Dalam penelitian ini, semua pengujian statistik menggunakan alfa atau $L o S$ sebesar .05. Berdasarkan data pada Tabel 4, dapat diketahui bahwa perilaku kerja inovatif $(M=4.04, S D=$ .94) memiliki korelasi yang positif dan signifikan dengan efikasi diri kreatif $(M=4.15, S D=.94)$; $r(538)=.67 ; p=.00(p<.01$, one-tailed $)$. Dengan demikian, dapat dikatakan bahwa hipotesis penelitian ini diterima karena didukung data. Hubungan yang ditemukan adalah positif dan signifikan yang berarti semakin tinggi efikasi diri kreatif mahasiswa, maka semakin tinggi pula perilaku kerja inovatif nya. Selanjutnya, effect size untuk analisis ini dapat dikatakan termasuk large effect karena $r=.67$, menurut Cohen (1988) jika $r$ e" .50 maka termasuk dalam large effect. Large effect ini menandakan bahwa hubungan antara variabel perilaku kerja inovatif dan efikasi diri kreatif ini kuat
Dalam penelitian ini, peneliti juga melakukan analisis dengan tujuan melihat perbedaan perilaku kerja inovatif di antara responden dengan membagi responden menjadi dua kategori yaitu, responden dengan perilaku kerja inovatif yang tinggi dan rendah. Pembagian kategori tersebut dapat dilakukan dengan membagi rata-rata Skor total responden yaitu 36.38 dengan jumlah butir yaitu sembilan, kemudian didapatkan nilai 4.04. Responden dengan rata-rata skor skala 4.04 dan lebih merupakan responden yang perilaku kerja inovatif nya termasuk dalam kategori tinggi, karena dalam menjawab alat ukur tersebut jawaban responden rata-rata adalah "agak sering melakukan". Sedangkan yang di bawah 4.04 termasuk dalam kategori rendah. Berikut ini merupakan gambaran perbedaan perilaku kerja inovatif individu jika dibagi menjadi kategori tinggi dan rendah:

\section{Tabel 5}

Gambaran Perbedaan Perilaku Kerja Inovatif Individu Berdasarkan Kategori Tinggi dan Rendah

\begin{tabular}{lccc}
\hline & Perilaku Kerja Inovatif & $n$ & $\%$ \\
\hline Kategori Tinggi & 284 & 52.69 \\
Kategori Rendah & 255 & 47.31 \\
$N$ & 539 & 100 \\
\hline
\end{tabular}

Berdasarkan Tabel 5, dapat diketahui bahwa responden penelitian yang memiliki perilaku kerja inovatif dalam kategori tinggi yaitu sejumlah 284 mahasiswa (52.69\%). Sedangkan sisanya yaitu, 255 mahasiswa (47.31\%) memiliki perilaku kerja inovatif dalam kategori rendah. Data tersebut menunjukkan bahwa sudah banyak mahasiswa Universitas " $X$ " yang memiliki perilaku kerja inovatif yang tinggi dalam kesehariannya mengerjakan tugas sebagai mahasiswa, tetapi masih banyak juga mahasiswa lain yang masih dalam kategori rendah. 
Selanjutnya, peneliti melakukan analisis dengan tujuan melihat perbedaan perilaku kerja inovatif mahasiswa berdasarkan karakteristiknya. Berikut merupakan tabel perbedaan perilaku kerja inovatif mahasiswa berdasarkan jenis kelamin, fakultas yang dikelompokkan berdasarkan rumpun ilmunya, serta kegiatan non akademis di dalam atau di luar kampus yang diikuti:

\section{Tabel 6}

Perilaku Kerja Inovatif Individu Berdasarkan Jenis Kelamin, Rumpun Ilmu, dan Kegiatan non Akademis

\begin{tabular}{lcccc}
\hline \multicolumn{1}{c}{ Karakteristik Individu } & $n$ & $M$ & $F$ ratio & $p$ \\
\hline Jenis Kelamin & & & & \\
$\quad$ Laki-laki & 185 & 4.1 & & \\
$\quad$ Perempuan & 354 & 4.01 & 1.05 & .31 \\
Rumpun ilmu & & & & \\
$\quad$ Rumpun Ilmu Kesehatan & 122 & 3.89 & & \\
$\quad$ Rumpun Ilmu Sains dan Teknologi & 189 & 4.15 & 2.92 & .06 \\
$\quad$ Rumpun Ilmu Sosial dan Humaniora & 228 & 4.01 & & \\
Kegiatan non akademis di dalam atau di luar kampus yang & & & & \\
$\quad$ diikuti & & & & \\
$\quad$ Mengikuti kegiatan non akademis & 436 & 4.08 & & \\
$\quad$ Tidak mengikuti kegiatan non akademis & 103 & 3.87 & 4.20 & .04 \\
\hline
\end{tabular}

Dalam penelitian ini, semua pengujian statistik yang dilakukan menggunakan alfa sebesar .05. Berdasarkan Tabel 6, dapat diketahui bahwa hanya kegiatan non akademis yang mampu menunjukkan bahwa terdapat perbedaan perilaku kerja inovatif yang signifikan antar mahasiswa. Hasilnya adalah $F(1.537)=4.20, p=.04(p<.05$, two-tailed $)$, yang menunjukkan bahwa mahasiswa yang mengikuti kegiatan non akademis di dalam atau di luar kampus atau kegiatan ekstrakurikuler ( $M$ $=4.08, S D=.93$ ) memiliki perilaku kerja inovatif yang lebih tinggi dibandingkan dengan mahasiswa yang tidak mengikuti $(M=3.87, S D$ = .96). Effect size untuk analisis ini adalah sebesar $d=.22$ yang tergolong small effect $(d<$ .50) Menruut Cohen (1988) karena effect sizenya termasuk small maka dapat dikatakan bahwa meskipun perbedaannya signifikan secara statistik tetapi hubungan kedua variabel ini lemah.

Peneliti juga melakukan analisis untuk melihat perbedaan efikasi diri kreatif di antara responden dengan membagi responden menjadi dua kategori yaitu, responden dengan efikasi diri kreatif yang tinggi dan rendah. Sama seperti sebelumnya, pembagian kategori tersebut dilakukan dengan membagi rata-rata skor total responden yaitu 16.6 dengan jumlah butir yaitu empat, kemudian didapatkan nilai 4.15. Responden yang rata-rata skor skalanya 4.15 atau lebih adalah responden dengan efikasi diri kreatif yang termasuk dalam kategori tinggi, karena responden rata-rata menjawab "agak setuju" pada butir-butir dalam alat ukur ini. Sedangkan responden yang di bawah 4.15 
termasuk dalam kategori rendah. Berikut ini merupakan gambaran perbedaan efikasi diri kreatif individu jika dibagi menjadi kategori tinggi dan rendah:

\section{Tabel 7}

Distribusi Frekuensi Efikasi Diri Kreatif Berdasarkan Kategorisasi

\begin{tabular}{cccc}
\hline Variabel & $n$ & $\%$ & Kategorisasi \\
\hline Efikasi Diri Kreatif & 282 & 52.31 & Tinggi \\
& 257 & 47.68 & Rendah \\
\hline
\end{tabular}

Berdasarkan Tabel 7 tersebut, peneliti dapat mengetahui bahwa responden penelitian yang memiliki efikasi diri kreatif dalam kategori tinggi berjumlah 282 orang (52.31\%). Lalu ada 257 orang (47.31\%) yang memiliki perilaku kerja inovatif dalam kategori rendah. Data tersebut menunjukkan bahwa sudah banyak mahasiswa Universitas "X" yang memiliki efikasi diri kreatif yang tinggi dalam kesehariannya sebagai mahasiswa, tetapi masih ada banyak juga mahasiswa lain yang masih dalam kategori rendah.

Peneliti selanjutnya juga menganalisis kembali variabel efikasi diri kreatif untuk melihat perbedaannya di antara individu. Di bawah ini adalah tabel perbedaan efikasi diri kreatif individu berdasarkan karakteristik individu berupa jenis kelamin, fakultas yang dikelompokkan berdasarkan rumpun ilmunya, serta kegiatan non akademis di dalam atau di luar kampus yang diikuti:

\section{Tabel 8}

Efikasi Diri Kreatif Berdasarkan Jenis Kelamin, Rumpun Ilmu, dan Kegiatan non Akademis

\begin{tabular}{lcccc}
\hline \multicolumn{1}{c}{ Karakteristik Individu } & $n$ & $M$ & $F$ ratio & $p$ \\
\hline Jenis Kelamin & & & & \\
$\quad$ Laki-laki & 185 & 4.34 & & \\
$\quad$ Perempuan & 354 & 4.05 & 11.25 & .001 \\
Rumpun ilmu & & & & \\
$\quad$ Rumpun Ilmu Kesehatan & 122 & 4.09 & & \\
$\quad$ Rumpun Ilmu Sains dan Teknologi & 189 & 4.07 & 1.99 & .14 \\
$\quad$ Rumpun Ilmu Sosial dan Humaniora & 228 & 4.25 & & \\
Kegiatan non akademis di dalam atau di luar kampus yang & & & & \\
$\quad$ diikuti & & & & \\
$\quad$ Mengikuti kegiatan non akademis & 436 & 4.21 & & \\
$\quad$ Tidak mengikuti kegiatan non akademis & 103 & 3.92 & 7.76 & .006 \\
\hline
\end{tabular}

Sama seperti analisis sebelumnya, semua pengujian statistik yang dilakukan menggunakan alfa sebesar .05. Berdasarkan Tabel 8, dapat diketahui bahwa perbedaan efikasi diri kreatif antar mahasiswa hanya bisa dilihat dari jenis kelamin dan kegiatan non akademis. Pertama, dengan menggunakan uji one-way ANOVA peneliti mengetahui bahwa ada perbedaan yang signifikan dari efikasi diri kreatif mahasiswa laki-laki dan perempuan, 
$F(1.537)=11.25, p=.001,(p<.05$, two-tailed $)$. Hasil ini menunjukkan bahwa mahasiswa lakilaki $(M=4.34, S D=.97)$ memiliki efikasi diri kreatif yang lebih tinggi dibandingkan dengan mahasiswa perempuan $(M=4.05, S D=.92)$. Effect size untuk analisis ini adalah sebesar $d=$ .30 yang tergolong small effect $(d<.50)$ (Cohen, 1988), karena effect size-nya termasuk small maka dapat dikatakan bahwa meskipun perbedaannya signifikan secara statistik tetapi hubungan kedua variabel ini lemah.

Peneliti kemudian menghitung perbedaan efikasi diri kreatif individu berdasarkan kegiatan non akademisnya. Hasilnya adalah $F(1.537)=7.76, p=.006,(p<$ .05 , two-tailed), yang menunjukkan bahwa mahasiswa yang mengikuti kegiatan non akademis atau ekstrakurikuler $(M=4.21, S D=$ .92) memiliki efikasi diri kreatif yang lebih tinggi dibandingkan dengan mahasiswa yang tidak mengikuti $(M=3.92, S D=.99)$. Effect size untuk analisis ini adalah sebesar $d=.29$ yang tergolong small effect $(d<.50)$ (Cohen, 1988), karena effect size-nya termasuk small maka dapat dikatakan bahwa meskipun perbedaannya signifikan secara statistik tetapi hubungan kedua variabel ini lemah.

\section{Pembahasan}

Berdasarkan analisis yang telah dilakukan peneliti menemukan bahwa efikasi diri kreatif pada mahasiswa memiliki hubungan yang positif dan signifikan dengan perilaku kerja inovatif mereka. Hal ini berarti bahwa semakin tinggi efikasi diri kreatif mahasiswa, maka perilaku kerja inovatif mereka akan semakin tinggi juga. Hasil tersebut sama dengan penelitian-penelitan sebelumnya yang juga menemukan adanya hubungan yang positif dan signifikan antara variabel efikasi diri kreatif dan perilaku kerja inovatif (Hsu et al., 2011; Li \& Wu, 2011; Slåtten, 2014), meskipun banyak di antaranya dilakukan pada karyawan bukan mahasiswa.

Mahasiswa sendiri tidak terlepas dari memiliki banyak tanggung jawab seperti harus menyelesaikan tugas-tugas akademis setiap harinya. Mulai dari tugas individu ataupun tugas kelompok, ditambah lagi tugas lain seperti harus belajar untuk kuis atau ujian lain yang akan datang. Hal-hal tersebut bisa menjadi sumber masalah dan stres bagi mahasiswa ketika tidak bisa menyelesaikan tepat waktu, terlebih lagi tugas yang harus diselesaikan bisa lebih dari satu mata kuliah. Memiliki perilaku kerja inovatif ini kemudian menjadi sangat penting bagi mahasiswa karena bisa menjadi problem-focused coping yang membantunya untuk menyelesaikan masalah dan mengatasi stres yang dirasakan dari tugas-tugas dengan lebih baik (Janssen, 2000; Janssen et al., 2004). Perilaku kerja inovatif membuat mahasiswa bisa mengimplementasikan metode, prosedur, atau pendekatan baru untuk bisa mengerjakan tugas-tugas yang harus diselesaikannya dengan lebih baik.

Efikasi diri kreatif yang dimiliki individu berhubungan dengan perilaku kerja 
inovatif nya karena mampu menyediakan keyakinan yang kuat untuk meningkatkan tingkat kegigihan dan sikap dalam upaya tersebut, yang kemudian mampu meningkatkan kepercayaan diri individu (Tierney \& Farmer, 2002). Efikasi diri kreatif tersebut membuat individu mampu mengatasi ketidakpastian dan kegagalan yang mungkin muncul ketika individu tersebut berusaha mengatasi masalah dengan perilaku kerja inovatifnya (Hsu et al, 2011). Individu seperti ini akan terus berpikir secara kritis untuk menemukan ide atau solusi yang inovatif (Supriatna, 2019). Pada saat efikasi diri kreatifnya tinggi, individu akan meluangkan waktu yang lebih banyak pada proses kognitif untuk menghasilkan ide. Tahap-tahap selanjutnya yaitu, mempromosikan ide dan merealisasikan kemudian akan berlangsung dengan lebih baik dan lancar karena telah didukung oleh efikasi diri kreatif yang tinggi tersebut. Individu tersebut kemudian dapat mengerjakan pekerjaan yang spesifik dengan lebih baik dan bisa meraih tujuan inovasi (Hsu et al., 2011; Tierney \& Farmer, 2002).

Berdasarkan analisis data demografis atau karakteristik individu dapat diketahui bahwa perbedaan perilaku kerja inovatif antar mahasiswa hanya bisa dilihat dari data demografis kegiatan non akademis di dalam atau di luar kampus, yang dibagi menjadi kategori mengikuti kegiatan dan tidak mengikuti kegiatan apapun. Ketai et al. (2011) menyatakan bahwa kegiatan ekstrakurikuler merupakan langkah utama untuk meningkatkan aktivitas inovasi dari mahasiswa. Kegiatan non akademis atau ekstrakurikuler yang mereka ikuti bisa memberikan lebih banyak kesempatan kepada mereka untuk secara aktif membuat ide-ide yang inovatif untuk mengatasi masalah yang ditemui.

Pada penelitian ini tidak ditemukan adanya perbedaan perilaku kerja inovatif berdasarkan jenis kelamin, hasil ini sejalan dengan penelitian Etikariena (2018) meski pada responden yang berbeda yaitu di kalangan karyawan. Akan tetapi, hasil penelitian ini tidak tidak sejalan dengan penelitian yang dilakukan dalam konteks organisasi seperti penelitian Østergaard (2011) dan Janssen (2000) yang menemukan adanya perbedaan perilaku kerja inovatif antara perempuan dan laki-laki. Hal ini bisa saja terjadi karena dalam organisasi lakilaki lebih sering memegang jabatan yang lebih tinggi, sehingga memiliki kekuasaan yang berbeda dalam menerapkan perilaku kerja inovatif (Kim et al, 2016; Park et al, 2017; Powell et al., 2002). Sedangkan, di universitas tidak ada perbedaan tingkat jabatan seperti itu. Mahasiswa laki-laki dan perempuan berada pada level yang sama dalam mengerjakan tugastugasnya (Martín et al, 2017), sehingga perilaku kerja inovatifnya tidak berbeda secara signifikan.

Tidak ada juga perbedaan yang signifikan antara mahasiswa yang berasal dari fakultas yang berbeda yang dalam penelitian ini fakultas yang ada dikategorikan dalam tiga rumpun ilmu, 
yaitu: Rumpun Ilmu Kesehatan, Rumpun Ilmu Sains dan Teknologi, serta Rumpun Ilmu Sosial dan Humaniora. Hasilnya berbeda dengan penelitian sebelumya yang dilakukan oleh Martin et al. (2017) yang menemukan bahwa mahasiswa Seni Rupa menunjukkan perilaku kerja inovatif yang lebih tinggi dibandingkan mahasiswa lain. Hal tersebut disebabkan oleh mahasiswa Seni Rupa memiliki kebebasan yang lebih untuk menerapkan ide inovatif nya. Akan tetapi, tidak ada jurusan Seni Rupa di Universitas Indonesia, jurusan Arsitektur yang hampir serupa tugas-tugasnya juga tidak membuat adanya perbedaan yang signifikan pada perilaku kerja inovatif antar mahasiswa. Hal yang menarik ditemukan dalam hasil analisis ini, meskipun perbedaannya tidak signifikan mahasiswa dari Rumpun Ilmu Sains dan Teknologi memiliki rata-rata perilaku kerja inovatif yang sedikit lebih tinggi dibandingan mahasiswa dari rumpun ilmu lain. Meskipun tugas-tugas mahasiswa di setiap rumpun kurang lebih sama, mahasiswa dari Rumpun Ilmu Sains dan Teknologi bisa memiliki rata-rata perilaku kerja inovatif yang sedikit lebih tinggi kemungkinan disebabkan oleh lebih banyaknya praktikum. Mereka lebih sering dihadapkan dengan pembelajaran yang mengharuskannya membuat ide atau solusi yang inovatif dan mempraktikannya secara langsung untuk masalah yang nyata, khusunya mahasiswa Fakultas Teknik yang memang sangat berhubungan dengan aktivitas inovasi (Badran, 2007).
Selanjutnya, peneliti juga melakukan analisis perbedaan efikasi diri kreatif antar mahasiswa berdasarkan data demografis atau karakteristik individunya. Berdasarkan hasil analisis ini, dapat diketahui bahwa perbedaan efikasi diri kreatif antar mahasiswa hanya bisa dilihat dari data demografis jenis kelamin. Hasil tersebut sama dengan penelitian yang dilakukan oleh Beghetto (2006) dan Karwowski (2011). Dari hasil analisis dapat diketahui bahwa mahasiswa laki-laki mempunyai efikasi diri kreatif yang lebih tinggi daripada mahasiswa perempuan. Perbedaan tersebut dapat terjadi karena perbedaan persepsi tentang efikasi diri kreatif yang dimiliki. Karwowski (2011) lakilaki cenderung memiliki persepsi bahwa efikasi diri kreatifnya tinggi, sedangkan perempuan cenderung memiliki persepsi bahwa efikasi diri kreatifnya itu rendah.

Hasil analisis demografis ini juga mendukung hasil penelitian sebelumnya yang menyatakan bahwa kegiatan non akademis atau kegiatan ekstrakurikuler merupakan faktor yang berhubungan dengan efikasi diri kreatif seseorang (Beghetto, 2006; Forgeard \& Benson, 2019). Kegiatan-kegiatan seperti itu bisa membuat efikasi diri kreatif mahasiswa menjadi lebih tinggi karena memberikan lebih banyak kesempatan baginya untuk lebih aktif membuat ide-ide baru dan berguna, serta untuk membuat ide-ide kreatif. Mereka menjadi memiliki kesempatan untuk mengatasi masalah dengan cara yang orisinal dan efektif. Individu yang memiliki efikasi diri yang tinggi juga bisa 
mempertahankannya karena lebih terdorong untuk terus terlibat dalam kegiatan seperti ini (Forgeard \& Benson, 2019). Mahasiswa yang berasal dari fakultas atau rumpun ilmu yang berbeda juga tidak ditemukan memiliki perbedaan skor efikasi diri kreatif yang berbeda secara signifikan. Hal ini kemungkinan terjadi karena butir-butir dalam alat ukurnya menanyakan keyakinan individu dalam membuat ide-ide kreatif dalam tugas sehariharinya sebagai mahasiswa, sehingga tidak adanya perbedaan yang signifikan berdasarkan rumpun ilmu ini karena tugas-tugas mahasiswa yang cenderung sama. Seperti tugas kelompok membuat presentasi, makalah, dan belajar untuk ujian.

Adapun prevalensi perilaku kerja inovatif pada mahasiswa dalam beberapa penelitian yaitu berdasarkan hasil penelitian yang dilakukan Mikhailova dan Kaminskaya (2016) menunjukan dari sebanyak 100 mahasiswa psikologi dan mahasiswa ekonomi dengan rentang usia 18-25 tahun, ditemukan sebanyak 28\% mahasiswa memiliki perilaku kerja inovatif dengan level yang tinggi dan $72 \%$ sisanya menunjukkan perilaku kerja inovatif, dan sebanyak $12 \%$ mahasiswa memiliki tingkat perilaku kerja inovatif yang rendah. Mahasiswa ekonomi mendemonstrasikan hasil yang sama dengan mahasiswa psikologi dengan $28 \%$ level yang tinggi. Sedangkan $72 \%$ mahasiswa ekonomi level rata-rata. Mahasiswi ekonomi memunculkan perilaku inovatif pada level yang tinggi $4 \%$ dan mayoritas menunjukkan perilaku inovatif dengan level menengah. Dalam penelitian yang dilakukan oleh Lukina et al. (2019), perilaku inovatif ditunjukkan dengan cara yang berbeda oleh para respondennya. Pada kelompok satu, perilaku evaluasi yang muncul adalah dengan memunculkan beberapa ide yang simultan dan original. Kelompok dua, mereka bekerja dengan beberapa cara dan menyarankan solusi untuk mengatasi masalah dengan cara yang berbeda. Di kelompok tiga, mereka memunculkan kreativitas dan pemikiran jangka panjang. Dalam kelompok empat, mereka memunculkan interaksi antar anggota guna menstimulus munculnya emosi positif agar membantu proses pemecahan masalah.

Perilaku kerja inovatif memiliki berbagai macam dampak. Lukina et al. (2019). pada penelitiannnya menemukan bahwa perilaku kerja inovatif memunculkan ide yang original untuk menyelesaikan masalah dan membantu proses analisa ide. Hal ini juga didukung oleh penelitian dari Kim, et al. (2018). yang menjelaskan bahwa dampak penyelesaian masalah yang baik dapat mempengaruhi perilaku kerja inovatif yang baik. Perilaku inovatif juga dapat memunculkan kontrol perilaku konseptual, kontrak emosional dan norma individu (Kong \& Xu, 2020). Menurut Zhong, et al. (2018) pada penelitiannya juga berpendapat bahwa perilaku inovatif dapat memunculkan perilaku pencarian informasi. Perilaku inovatif memberikan pengaruh juga pada model pembelajaran (Rahmawati et al, 
2018). Helmi (2011) dalam penelitiannya menemukan bahwa adanya perilaku kerja inovatif dapat memunculkan rasa ingin tahu untuk memahami ilmu guna membantu pengambilan keputusan dalam berwirausaha. Ilmu pengetahuan dapat digunakan guna membantu untuk memahami cara menghadapi kompetitor, melakukan kalkulasi untuk mengambil resiko dan mengembangkan usahanya dengan cara berinovasi.

Berikut berbagai macam penyebab yang dapat mempengaruhi munculnya perilaku kerja inovatif. Chang (2018) dalam penelitiannya menemukan bahwa perilaku inovatif dapat memunculkan efikasi diri yang kreatif (creative self-efficacy) pada mahasiswa. Penelitian dari Li dan Wu (2011) juga menemukan bahwa optimisme dan efikasi diri yang kreatif dapat memunculkan perilaku kerja inovatif pada mahasiswa. Kemudian, Amalya (2019) menambahkan bahwa faktor-faktor yang menyebabkan perilaku inovatif adalah lingkungan, persepsi, emosi, konsep dan motivasi / tujuan. Ada komponen inovatif dari perilaku inovatif yang mempengaruhi perilaku inovatif.

Kemudian, Roffee et al. (2017) dalam penelitiannya menjelaskan budaya inovasi dapat mempengaruhi munculnya perilaku kerja inovatif. Bagaimana mahasiswa merespon atau mempersepsikan pembelajaran serta bahasa pendukung yang digunakan di universitas masing-masing mempengaruhi perilaku inovatif. Innovation culture juga mempengaruhi munculnya self-efficacy, climate for innovation dan effective communications. Pada penelitian yang dilakukan oleh Jose dan Mampilly (2017) dalam sebuah organisasi ditemukan bahwa career anchors adalah faktor yang menentukan perilaku kerja inovatif pada individu kedepannya, karena career anchors dijabarkan sebagai talenta, kemampuan, alasan, perilaku dan nilai yang terdapat pada diri seseorang, perbedaan persepsi dalam budaya organisasi. Career anchors merupakan faktor yang menentukan efikasi diri karena career anchors Maka career anchors dapat menentukan perilaku inovatif kerja pada individu kedepannya. Kemudian, persepsi organisational culture berkorelasi signifikan dengan perilaku inovatif kerja. Hal itu terjadi karena kultur organisasi dapat mengurangi stres yang mampu meningkatkan perilaku inovatif kerja. Kultur organisasi juga dapat memfasilitasi atau memunculkan inovasi pada setiap orang yang terlibat didalamnya. Perlakuan individu dan lingkungan kerja juga dapat mempengaruhi perilaku kerja inovatif.

Terdapat beberapa penelitian lain yang mendukung tentang efikasi diri dan perilaku kerja inovatif pada mahasiswa. Penelitian yang dilakukan oleh Prihatsanti (2018) ditemukan adanya hubungan yang positif signifikan antara perilaku inovatif pada mahasiswa yang memiliki bisnis dengan efikasi diri berwirausaha. Lee et al. (2019) menemukan bahwa start-up intention memilki hubungan signifikan positif dengan perilaku kerja inovatif. 
Dalam penelitian yang dilakukan oleh Ibus dan Ismail (2018) ditemukan bahwa terdapat pengaruh signifikan antara self-leadership dan inovatif. Lalu ditemukan adanya hubungan yang signifikan antara efikasi diri dan perilaku inovatif kerja. Terdapat juga hubungan yang signifikan antara berbagi pengetahuan dan perilaku inovatif kejra.

\section{Simpulan}

Penelitian ini bertujuan untuk mengetahui lebih banyak informasi mengenai perilaku kerja inovatif pada mahasiswa di Indonesia. Berdasarkan hasil dan analisis utama penelitian yang telah dilakukan, dapat disimpulkan bahwa terdapat hubungan yang positif dan signifikan antara efikasi diri kreatif dan perilaku kerja inovatif pada mahasiswa. Hasil ini menandakan bahwa hipotesis penelitian ini diterima karena didukung data. Hal tersebut menunjukkan bahwa semakin tinggi efikasi diri kreatif seorang mahasiswa maka akan semakin tinggi pula perilaku kerja inovatifnya. Selanjutnya berdasarkan hasil perhitungan pada gambaran umum variabel, mayoritas responden sudah memiliki perilaku kerja inovatif yang tinggi. Diketahui pula bahwa sebagian besar responden sudah memiliki efikasi diri kreatif yang tergolong tinggi.

Berdasarkan hasil analisis data demografisnya dapat disimpulkan bahwa hanya terdapat perbedaan perilaku kerja inovatif berdasarkan data demografis kegiatan non akademis di dalam atau di luar kampus.
Mahasiswa yang mengikuti kegiatan non akademis ditemukan memiliki perilaku kerja inovatif yang lebih tinggi daripada mahasiswa yang tidak mengikuti. Pada variabel efikasi diri kreatif dapat disimpulkan bahwa hanya data demografis jenis kelamin dan kegiatan non akademis di dalam atau di luar kampus yang mampu membedakan efikasi diri kreatif antar mahasiswa. Mahasiswa laki-laki mempunyai efikasi diri kreatif yang lebih tinggi daripada mahasiswa perempuan. Mahasiswa yang mengikuti kegiatan non akademis ditemukan memiliki efikasi diri kreatif yang sedikit lebih tinggi daripada mahasiswa yang tidak mengikuti kegiatan non akademis.

\section{Saran}

Berdasarkan hasil penelitian, peneliti memiliki beberapa saran praktis. Yang pertama kepada mahasiswa peneliti menyarankan agar mengikuti berbagai macam kegiatan non akademis di dalam atau di luar kampus yang diminati. Mahasiswa juga disarankan untuk mengikuti kompetisi-kompetisi seperti Program Kreativitas Mahasiswa yang diselenggarakan oleh Kementrian Riset, Teknologi, dan Pendidikan Tinggi agar mahasiswa menjadi kreatif dan inovatif dengan berkreasi sekaligus menerapkan ilmu yang dipelajarinya di perkuliahan agar bermanfaat bagi masyarakat luas. Mengikuti kegiatan seperti ini bisa mempertahankan dan juga meningkatkan efikasi diri kreatif dan perilaku kerja inovatif mahasiswa. 
Kepada pihak universitas khususnya dalam penelitian ini adalah Universitas "X" bisa melakukan upaya berupa menerapkan kegiatan belajar serta mengajar yang bisa membantu mahasiswa untuk lebih aktif menerapkan perilaku kerja inovatif dan efikasi diri kreatif. Upaya lain yang bisa dilakukan oleh Universitas " $\mathrm{X}$ " adalah mendorong mahasiswanya untuk lebih aktif mengikuti kegiatan non akademis dan kegiatan non-akademis yang paling disarankan adalah kegiatan magang. Setiap fakultas di Universitas " $\mathrm{X}$ " disarankan untuk mempertimbangkan kegiatan magang bagi mahasiswanya sebagai langkah peralihan dari dunia kampus ke dunia kerja. Dengan demikian diharapkan mereka bisa memiliki pengalaman nyata mengenai dunia kerja dan bagaimana menerapkan perilaku kerja inovatif ini di tempat kerja. Hal tersebut akan membuat mahasiswa bisa mempersiapkan dirinya untuk memasuki dunia kerja dengan lebih baik.

Penelitian ini tidak terlepas dari keterbatasan, yang pertama adalah mengenai persebaran responden berdasarkan data demografis asal fakultas tidak merata. Yang kedua adalah peneliti tidak melakukan revisi terhadap satu butir dalam alat ukur Perilaku Kerja Inovatif yang memiliki proportion of endorsement yang termasuk tinggi. Yang ketiga, sampel penelitian ini hanya mahasiswa S1 dari Universitas "X". Sampel yang merupakan mahasiswa dari Universitas "X" saja menjadi tantangan bagi penelitian selanjutnya untuk melanjutkan studi dengan melibatkan sampel mahasiswa dari universitas negeri dan swasta lainnya serta dari berbagai daerah. Hal tersebut perlu dilakukan karena hasil yang positif dan signifikan dari hubungan antara perilaku kerja inovatif dan efikasi diri kreatif bisa disebabkan oleh mahasiswa Universitas " $\mathrm{X}$ " merupakan mahasiswa yang sudah terpilih. Jadi, memang dari awal sudah banyak yang memiliki perilaku kerja inovatif dan efikasi diri kreatif yang sudah tinggi. Penelitian ini juga belum meneliti karakteristik individu berupa perbedaan budaya, karena terdapat kemungkinan bahwa mahasiswa dengan latar budaya yang berbeda akan memiliki perilaku kerja inovatif yang berbeda pula.

Berdasarkan keterbatasan-keterbatasan tersebut peneliti memberikan beberapa saran yang bisa dipertimbangkan untuk melakukan penelitian selanjutnya. Yang pertama, penelitian selanjutnya bisa mendapatkan responden dengan jumlah yang seimbang di setiap fakultasnya. Yang kedua, penelitian selanjutnya disarankan untuk melakukan revisi pada butir dalam tahapan menciptakan ide yaitu, "Mencari cara baru untuk mengerjakan tugas saya" sebelum melaksanakan penelitian. Yang ketiga, penelitian ini dapat dikembangkan dengan sampel penelitian yang berasal dari perguruan tinggi negeri dan swasta yang berbeda-beda atau bahkan dari daerah yang berbeda-beda di Indonesia. Hal tersebut dimaksudkan agar hasil penelitiannya benar-benar mampu merepresentasikan populasinya yaitu mahasiswa di Indonesia. Diharapkan juga 
penelitian ini bisa mendapatkan hasil apakah mahasiswa dengan latar belakang budaya yang berbeda memiliki perilaku kerja inovatif yang berbeda, sehingga hasil yang didapatkan oleh penelitian ini bisa lebih kaya.

\section{Ucapan terima kasih}

Penelitian ini terlaksana berkat adanya dukungan Hibah Riset Dasar dari Fakultas Psikologi Universitas "X". Karenanya kami sebagai peneliti mengucapkan terima kasih banyak atas dukungan tersebut sehingga selesainya penelitian dan artikel jurnal ini.

\section{Referensi}

Abdullah, I., Omar, R., \& Panatik, S. A. (2016). A literature review on personality, creativity and innovative behavior ISSN: International Review of Management and Marketing, 6, 177-182.

Agarwal, U. A. (2014). Examining the impact of social exchange relationships on innovative work behaviour: Role of work engagement. Team Performance Management, 20(3/4), 102-120. https:/ /doi.org/10.1108/TPM-01-2013-0004

Amalya, I. (2019). Perilaku inovatif pada mahasiswa yang berwirausaha. Indonesian Psychological Research, 1(1), 40-46. https:/ /doi.org/10.29080/ipr.v1i1.169

Åmo, B. W., \& Kolvereid, L. (2005). Organizational strategy, individual personality and innovation behavior. Journal of Enterprising Culture (JEC), 13(1), 7-19. https://doi.org/10.1142/ S0218495805000033

Antoncic, B., \& Hisrich, R. D. (2001). Intrapreneurship: Construct refinement and cross-cultural validation. Journal of Business Venturing, 16(5), 495-527. https: / / doi.org/10.1016/S0883 9026(99)00054-3
Badran, I. (2007). Enhancing creativity and innovation in engineering education. European Journal of Engineering Education, 32(5), 573-585. https:// doi.org/10.1080/03043790701433061

Bandura, A. (1997). Self-efficacy: The exercise of control. W.H. Freeman and Company.

Baumann, P. K. (2011). The relationship between individual and organizational characteristics and nurse innovation behavior [Indiana University]. http:// hdl.handle.net/1805/2603

Beghetto, R. A. (2006). Creative self-efficacy: Correlates in middle and secondary students. Creativity Research Journal, 18(4), 447-457. https://doi.org/ 10.1207/s15326934crj1804_4

Berinsky, A. J., Margolis, M. F., \& Sances, M.W. (2013). Separating the shirkers from the workers? Makingsurerespondents pay attention on selfadministered surveys. American Journal of Political Science, 58(3), 739-753. http:// www.jstor.org/stable/24363518

Bysted, R., \& Jespersen, K. R. (2014). Exploring managerial mechanisms that influence innovative work behaviour: Comparing private and public employees. Public ManagementReview,16(2),217-241.https:/ /doi.org/10.1080/14719037.2013.806576

Chang, Y. C. (2018). Analyzing the moderating effect of knowledge innovation of tourism and hospitality department teachers on student creative self-efficacy and innovation behaviors by using hierarchical linear modeling. Cogent Education, 5(1), 1535755. https:// d o i . o r g / 10 . 1080 / 2331186X.2018.1535755

Chang, Y. C., \& Yang, Y. L. (2012). The effect of organization's innovational climate on student's creative self-efficacy and innovative behavior. Business \& Entrepreneurship Journal, 1, 75-100.

Cohen, J. (1988). Statistical power analysis for the behavioral sciences (2nd ed.). Lawrence Earlbaum Associates. 
Egan, T. M. (2005). Factors influencing individual creativity in the workplace: An examination of quantitative empirical research. Advances in Developing Human Resources, 7, 160-181. https:// doi.org/bh6682

Etikariena, A. (2017). Analisis efek mediasi identitas organisasi dan kesiapan karyawan untuk berinovasi pada hubungan antara memori organisasi dengan perilaku kerja inovatif (Unpublished doctoral dissertation). Universitas Indonesia,Depok.

Etikariena, A. (2018). Perbedaan perilaku kerja inovatif berdasarkan karakteristik individu karyawan. Jurnal Psikologi, 17(2), 107-118. https://doi.org/ 10.14710/jp.17.2.107-118

Etikariena, A., \& Muluk, H. (2014). Hubungan antara memori organisasi dan perilaku inovatif karyawan. Hubs-Asia, 18(2), 77-88. https://doi.org/10.7454/ mssh.v18i2.3463

Field, A. (2009). Discovering statistics using SPSS (3rd ed.). Sage Publications.

Forgeard, M. J. C., \& Benson, L. (2019). Extracurricular involvement and psychological adjustment in the transition from adolescence to emerging adulthood: The role of mastery and creative self-efficacy. Applied Developmental Science, 23(1), 41-58. h t tp s: / / do i.org / 10.1080 / 10888691.2017.1288124

Gravetter, F. J., \& Forzano, L. B. (2012). Research methods for the behavioral sciences (4th ed.). Cengage Learning.

Gravetter, F. J., \& Wallnau, L. B. (2013). Statistics for the behavioral sciences (9th ed.). Cengage Learning.

Hammond, M. M., Neff, N. L., Farr, J. L., Schwall, A. R., \& Zhao, X. (2011). Predictors of individual-level innovation at work: A meta-analysis. Psychology of Aesthetics, Creativity, and the Arts, 5(1), 90-105. https://doi.org/10.1037/a0018556
Helmi, A. F. (2011). Model determinan perilaku inovatif pada mahasiswa yang berwirausaha. Jurnal Psikologi, 38(2), 134-146. https://doi.org/10.22146/ jpsi.7648

Hsu, M. L. A., Hou, S. T., \& Fan, H. L. (2011). Creative self-efficacy and innovative behavior in a service setting: optimism as a moderator. The Journal of Creative Behavior, 45, 258-272. https://doi.org/ 10.1002/j.2162-6057.2011.tb01430.x

Ibus, S., \& Ismail, F. (2018). Conceptual framework: The mediating effect of selfefficacy in the relationships of selfleadership, knowledge sharing, and innovative work behaviour. International Journal of Academic Research in Business and Social Sciences, 8. https://doi.org/10.6007/IJARBSS/v8i11/5378

Janssen, O. (2000). Job demands, perceptions of effort reward fairness and innovative work behaviour. Journal of Occupational and Organizational Psychology, 73, 287302. https://doi.org/10.1348/ 096317900167038

Janssen, O., Van de Vliert, E., \& West, M. (2004). The bright and dark sides of individual and group innovation: A special issue introduction. Journal of Organizational Behavior, 25, 129-145. https://doi.org/ 10.1002/job.242.

Jose, S., \& Mampilly, S. R. (2017). Innovative work behaviour: Propositions on influence from within and without an individual in the organisational context. Asia-Pacific Journal of Management Research and Innovation, 12(3-4), 232237. https://doi.org/10.1177/ 2319510X17696649

Kaplan, R. M., \& Saccuzzo. (2009). Psychological testing: Principles, application, and issues (7th ed.). Thomson Wadsworth.

Karwowski, M. (2011). It doesn't hurt to ask...but sometimes it hurts to believe: Polish students' creative self-efficacy and its predictors. Psychology of Aesthetics, 
Creativity, and the Arts, 5(2), 154-164. https://doi.org/10.1037/a0021427

Ketai, H., Xiaoli, L., \& Li, L. (2011). Cultivating innovation capabilities of undergraduate students in extracurricular activities. 6th IEEE Conference on Industrial Electronics and Applications, 14881491. https://doi.org/10.1109/ iciea.2011.5975825

Kim, J. Y., Choi, D. S., Sung, C. S., \& Park, J. Y. (2018). The role of problem solving ability on innovative behavior and opportunity recognition in university students. Journal of Open Innovation: Technology, Market and Complexity, 4(4). https://doi.org/10.1186/s40852-0180085-4

Kim, W., Khan, G. F., Wood, J., \& Mahmood, M. T. (2016). Employee engagement for sustainable organizations: Keyword analysis using social network analysis and burst detection approach. Sustainability, 8(7), 631. https://doi.org/ $10.3390 /$ su8070631

Kleysen, R. F., \& Street, C. T. (2001). Towards a multi-dimensional measure of individual innovative work behavior. Journal of Intellectual Capital, 2(3), 284-296. h ttps://doi.org / 10.1108 / eum0000000005660

Kong, D., \& Xu, A. (2020). Innovative behavior mechanism of knoledgeable talents: An empirical analysis based on psychological contract. Revista Argentina de Clínica Psicológica, 29(2), 1342-1350. https://doi.org/10.24205/ 03276716.2020 .376

Kumar, R. (2011). Research methodology: A step-by-step guide for beginners (3rd ed.). Sage.

Lee, J., Kim, D., \& Sung, S. (2019). The effect of entrepreneurship on start-up open innovation: Innovative behavior of university students. Journal of Open Innovation: Technology, Market, and Complexity, 5(103), 1-13. https:// doi.org/10.3390/joitmc5040103
Li, C., \& Wu, J. (2011). The structural relationships between optimism and innovative behavior: Understanding potential antecedents and mediating effects. Creativity Research Journal, 23(2), 119-128. https://doi.org/ 10.1080/10400419.2011.571184

Lukina, V., Sidorova, T., \& Nafanailova, M. (2019). Experience of studying innovative behavior of youth in Russia. International Journal of Theory and Application in Elementary and Secondary School Education, 1(1), 98106. https://doi.org/10.31098/ ijtaese.v1i1.22

Martín, P., Potoènik, K., \& Fras, A. B. (2017). Determinants of students' innovation in higher education. Studies in Higher Education, 42, 1229-1243. https:// d o i . o r g / 10 . 1008 / 03075079.2015 .1087993

Mikhailova, O. B., \& Kaminskaya, E. A. (2016). Gender characteristics of the students innovative behavior. The Social Sciences, 11(18), 4483-4488. https://doi.org/ 10.36478/sscience.2016.4483.4488

Ng, T. W. H., \& Lucianetti, L. (2016). Withinindividual increases in innovative behavior and creative, persuasion, and change self-efficacy over time: A socialcognitive theory perspective. The Journal of Applied Psychology, 101(1), 14-34. https://doi.org/10.1037/ apl0000029

Omri, W. (2015). Innovative behavior and venture performance of SMEs: The moderating effect of environmental dynamism. European Journal of Innovation Management, 18, 195-217. https://doi.org/10.1108/EJIM-02-20130015

Oppenheimer, D. M., Meyvis, T., \& Davidenko, N. (2009). Instructional manipulation checks: Detecting satisficing to increase statistical power.Journal of Experimental Social Psychology, 45(4), 867-872. h ttp s: / / doi.org/10.1016/ j.jesp.2009.03.009 
Østergaard, C. R., Timmermans, B., \& Kristinsson, K. (2011). Does a different view create something new? The effect of employee diversity on innovation. Research Policy, 40(3), 500-509. https:/ /doi.org/10.1016/j.respol.2010.11.004

Park, S. G., Kang, H. J. A., Lee, H. R., \& Kim, S. J. (2017). The effects of $\operatorname{lmx}$ on gender discrimination and subjective career success. Asia Pacific Journal of Human Resources, 55(1), 127-148. https:// doi.org/10.1111/1744-7941.12098

Powell, G. N., Butterfield, D. D., \& Parent, J. D. (2002). Gender and managerial stereotypes: Have the times changed? Journal of Management, 28(2), 177-193. h t tp s : / / doi.org / $10.1177 /$ 014920630202800203

Prihatsanti, U. (2018). The Relationship Between Entrepreneurial Self-Efficacy, Entrepreneurial Curiosity and Innovative Behavior on Entrepreneur Students. https://doi.org/10.2991/ acpch-17.2018.31

Rahmawati, R., Ridlo, S., \& Sukaesih, S. (2018). Analysis of the effectiveness of learning models against students' innovative behaviour. Journal of Biology Education, 7(2), 127-136. https://doi.org/ 10.15294/jbe.v7i2.24266

Roffeei, S. H. M., Kamarulzaman, Y., \& Yusop, F. D. (2017). Inculcating innovative behaviour among students: Determinants of innovation culture in malaysian higher education. Malaysian Online Journal of Educational Management, 5(4), 1-17. h ttps : / / doi.org / 10.22452 / mojem.vol5no4.1

Scott, S. G., \& Bruce, R. A. (1994). Determinants of innovative behavior: A path model of individual innovation in the workplace. The Academy of Management Journal, 37, 580-607. https://doi.org/10.2307/ 256701

Slåtten, T. (2014). Determinants and effects of employee's creative self-efficacy on innovative activities. International
Journal of Quality and Service Sciences, 6, 326-347. https://doi.org/10.1108/ IJQSS-03-2013-0013

Southall, J., Wason, H., \& Avery, B. (2016). Nontraditional, commuter students and their transition to Higher Education - a synthesis of recent literature to enhance understanding of their needs. Student Engagement and Experience Journal, 5(1), 1-15. https://doi.org/10.7190/ seej.v4i1.128

Supriatna, M. D. (2019). The role of creative selfefficacy to increase researcher's innovative behavior. International Journal of Academic Research in Business and Social Sciences, 9(9), 846-859. https://doi.org/10.6007/IJARBSS/v9i9/6376

Tierney, P., \& Farmer, S. M. (2002). Creative selfefficacy: Its potential antecedents and relationship to creative performance. The Academy of Management Journal, 45(6), 1137-1148. https://doi.org/ $10.2307 / 3069429$

Tierney, P., \& Farmer, S. M. (2011). Creative selfefficacy development and creative performance over time. The Journal of Applied Psychology, 96(2), 277-293. https://doi.org/10.1037/a0020952

Trautwein, C., \& Bosse, E. (2017). The first year in higher education-critical requirements from the student perspective. Higher Education, 73(3), 371-387. https://doi.org/10.1007/ s10734-016-0098-5

West, M. (2002). Sparkling fountains or stagnant ponds: An integrative model of creativity and innovation implementation in work groups. Applied Psychology, 51(3), 355-387. https:// doi.org/10.1111/1464-0597.00951

Yuan, F., \& Woodman, R. W. (2010). Innovative behavior in the workplace: The role of performance and image outcome expectations. Academy of Management Journal, 53(2), 323-342. https://doi.org/ 10.5465/AMJ.2010.49388995 
Zhong, Z., Hu, D., Zheng, F., Ding, S., \& Luo, A. (2018). Relationship between information-seeking behavior and innovative behavior in Chinese nursing students. Nurse Education Today, 63, 15. https://doi.org/https://doi.org/ 10.1016/j.nedt.2018.01.004

Zhou, J., \& George, J. M. (2001). When job dissatisfaction leads to creativity:
Encouraging the expression of voice. The Academy of Management Journal, 44(4), 682-696. https://doi.org/ $10.2307 / 3069410$

Received 9 September 2020

Revised 30 October 2020

Accepted 5 January 2021 
